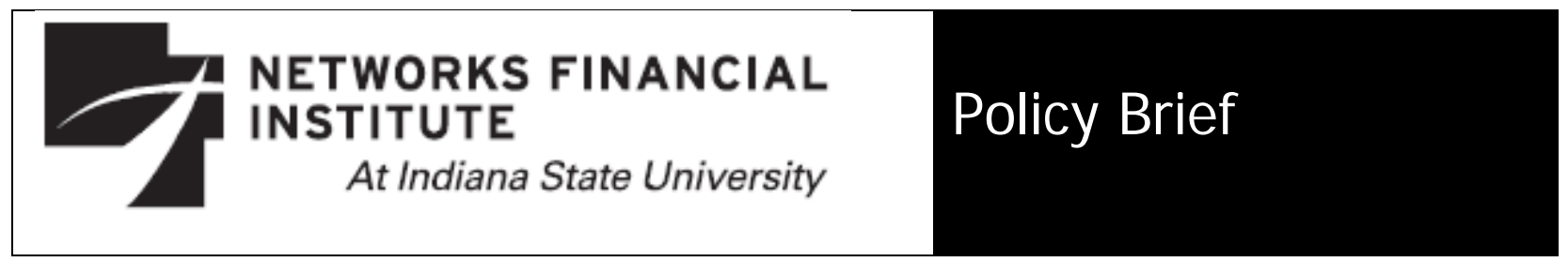

2009-PB-10

December 2009

\title{
Personal Finance: Past, Present and Future
}

Tahira K. Hira

Abstract: In recent years, the need for financial education has gained the attention of a wide range of entities including banking companies, government agencies, grass-roots consumer and community interest groups, universities, schools, and other organizations. Numerous factors have led to a complex, specialized financial services marketplace that requires consumers to be actively engaged if they are to manage their finances effectively. The prevailing concern is that consumers lack a working knowledge of financial concepts and do not have the tools they need to make decisions most advantageous to their economic wellbeing. However, a complex and specialized financial services marketplace requires consumers to be informed and actively engaged if they are to manage their finances effectively. Under these circumstances, there is a renewed attention to personal finance education. This subject matter is currently gaining attention from various quarters of society, such as academia, government, corporations and nonprofit organizations; however, many are not aware of the rich history and sources of literature in the field. This paper briefly reviews the history of personal finance and then looks at the current status of the personal financial discipline and education before identifying challenges and opportunities for the future.

About the Author: Tahira K. Hira is a professor of Personal Finance and Consumer Economics at lowa State University in Ames, lowa. Since 1976 she has taught and conducted research in family financial management, consumer credit, gambling, and consumer bankruptcy in the United States, Japan, United Kingdom, Canada, and New Zealand. She received a B.A. and M.A. degrees in Economics from Punjab University, Lahore, a M.S. in Agricultural Economics, and a Ph.D. in Family and Consumer Economics from the University of Missouri-Columbia. She joined I owa State University in 1980; currently, she serves as an Executive Assistant to the President at Iowa State University. Hira is a member of President's Council on Financial Literacy, and is currently serving on national strategy and core competencies working groups. She has published about 135 articles and book chapters and has made about 230 invited national and international presentations on topics such as the social and psychological aspects of the borrowing and investment behaviors of middle and high income Americans, consumer bankruptcy, consumer credit, gambling, and the borrowing behavior of college students.

Keywords: financial education, challenges of financial literacy, personal finance, financial counselors, financial planners, family economic wellbeing.

\section{JEL Classification: A12.}

The views expressed are those of the individual author and do not necessarily reflect official positions of Networks Financial Institute. Please address questions regarding content to Tahira Hira at tkhira@iastate.edu. Any errors or omissions are the responsibility of the author. NFI working papers and other publications are available on NFI's website (www.networksfinancialinstitute.org). Click "Thought Leadership" and then "Publications/Papers." 


\section{Personal Finance: Past, Present and Future \\ Tahira K. Hira}

\section{Introduction}

In recent years, the need for financial education has gained the attention of a wide range of entities including banking companies, government agencies, grass-roots consumer and community interest groups, universities, schools, and other organizations. Numerous factors have led to a complex, specialized financial services marketplace that requires consumers to be actively engaged if they are to manage their finances effectively. The forces of technology and market innovation, driven by increased competition, have resulted in a sophisticated industry in which consumers are offered a broad spectrum of services by a wide array of providers. Other important demographic and market trends contributing to concerns include increased diversity of the population, resulting in households that may face language, cultural, or other barriers to establishing a banking relationship; expanded access to credit for younger populations; and increased employee responsibility for directing their own investments in employer-sponsored retirement and pension plans.

The prevailing concern is that consumers lack a working knowledge of financial concepts and do not have the tools they need to make decisions most advantageous to their economic wellbeing. Financial decisions made by consumers affect an individual's or family's current financial wellbeing and ability to save for long-term goals such as buying a home, seeking higher education, or financing retirement. In addition, the consumer decisions also play an important role in the overall economic health of the nation, as was experienced through the recent economic crisis. 
Most recent economic issues such as credit card debt, home foreclosures, reduced savings, declining values of investments, the collapse of the subprime lending market, and escalating numbers of personal bankruptcy have focused the nation's attention on the importance of financial education.

Technological advances have transformed nearly every aspect of the marketing, delivery, and processing of financial products and service. The forces of technology and market innovation, driven by increased competition, have resulted in a sophisticated industry in which a wide array of providers offers consumers a broad spectrum of financial products and services. These developments have given consumers more options and greater flexibility in creating financial arrangements that best suit their needs. However, a complex and specialized financial services marketplace requires consumers to be informed and actively engaged if they are to manage their finances effectively.

While there are many causes to the economic problems facing the country, it is undeniable that a lack of financial education is a contributing factor. Far too many Americans entered into home and other loan agreements that they did not understand and ultimately could not afford. More broadly, the lack of basic skills such as how to create and maintain a budget, understand credit, or save for the future are preventing millions of Americans from taking advantage of our vibrant economic system. Financial education is not an issue unique to any one population. It affects everyone-men and women, young and old, across all racial and socioeconomic lines (U.S. Department of the Treasury, Office of Financial Education, 2008). 
Under these circumstances, there is a renewed attention to personal finance education. This subject matter is currently gaining attention from various quarters of society, such as academia, government, corporations and nonprofit organizations. There is an increasing recognition of the importance of this area within several academic quarters, such as economics and finance, that were traditionally not involved in this subject matter. One of the challenges, with increased interest from diverse programs, is the loss of focus on the family and more of a concentration on individual decision making. Financial education programs are now being referred to by a variety of names, the most frequently used name being "financial literacy"; however, the term financial literacy means different things to different people. There is no national standard that describes the expectations of a course labeled "financial literacy" regarding the core content, core competencies, assessment of the impact, and professional preparation of the teacher.

This paper briefly reviews the history of personal finance and then looks at the current status of the personal financial discipline and education before identifying challenges and opportunities for the future. In the final section, steps necessary to strengthen the future of this discipline are also presented.

\section{Personal Finance: An Interdisciplinary Approach}

Personal finance has its roots in economics, finance and management and incorporates general principles of decision making and the management of financial resources of the individual and family. It involves application of principles from a variety of disciplines such as economics, sociology, psychology, adult learning, and counseling to the study of ways that individuals, families, and households acquire, develop, and allocate monetary resources to meet their current and future financial needs. In the dynamic 
system of personal finance, decision makers are central. They influence and are influenced by various factors both in external and internal environments. This includes financial markets and institutions; government agencies; economic, demographic, and social trends; and personal and family factors. Personal finance encompasses tools such as financial statements, checking and savings accounts, debt instruments, mortgages and investment vehicles. It also includes techniques related to cash flow management; risk assessment and management; and planning of taxes, retirement, and estates (Schuchardt et al. 2007).

For over 100 years, the concepts have been taught in colleges of home economics (the past name). Research in personal finance was also being conducted as early as the 1920s with funds provided by the Hatch Act. Hazel Kyrk was instrumental in developing the field of family and consumption (or consumer) economics. In particular, her dissertation in economics at the University of Chicago, completed in 1920, laid the groundwork for the development of the field of consumption economics. Her later work laid the foundation for the field of family economics. She became an advocate for incorporating the insights of economics into the field of home economics and helped create the Division of Family Economics in the then American Home Economics Association. Margaret Reid, 1934, also a Chicago economist, is recognized as one of the pioneers in several areas of consumer and household behavior (Beller and Kiss, 1999).

Long before any specialty, emphasis, or a degree program in personal finance was formally offered across the nation, concepts closely related to personal finance were taught, and continue to be taught, under names such as family economics, consumer economics, consumption economics, family economics and resource management, household finances, family finances, and family financial management in the colleges of 
home economics (now known by names such as human sciences, family and consumer sciences, and human ecology, etc.).

However, personal finance is not just basic concepts related to math, finance, economics, entrepreneurship education, or information technology. Financial education goes beyond knowledge of these factors and recognizes that financial operations can be quite complex (Ginsburg, Manly, and Schmitt, 2006). Thus financial education is not solely a 'basic skills' issue since the mathematics involved may be anything but basic. Neither is it solely a numeracy issue: being financially literate entails literacy, as well as numeracy and decision-making skills (Coben, 2003). The underlying assumption in economics is that humans are rational. However, some people do not make rational and optimal decisions, and financial objectives are not entirely objective in nature. Ariely (2009) suggests that the global economic crisis has shattered two articles of faith in standard economic theory, that 1) human beings usually make rational decisions and that 2) the market's invisible hand serves as a trustworthy corrective to imbalance. As early as 1947, Nobel Prize winner Herbert Simon suggested that the decision maker possessed limited information (knowledge) and did not always seek the best potential choice because of limited resources and personal inclinations.

Financial education provides "individuals with the knowledge, aptitude, and skill base necessary to become questioning and informed consumers of financial services and manage their finances effectively" (Mason and Wilson, 2000, p. 5). Being financially educated means being knowledgeable about: a) money, credit, investments, banking, insurance, and taxes; b) the foundational concepts of financial management (e.g., risk, loss, gain); c) and being able to use this knowledge to plan and make sound financial decisions 
(Hogarth, 2002). The mission of the personal finance profession is different from the study of finance or economics. The focus in personal finance is not on the consumer or consumption but on the family/individual and their overall financial wellbeing. The end goals of personal finance education are to equip individuals and families with knowledge and skills to make informed and productive financial choices throughout various stages of the life cycle, choices that extend beyond their roles as consumers. It is about understanding the relationships between values, beliefs, attitudes, emotions, self-esteem and spending, borrowing, saving and investing (Schuchardt, 2007).

Prior to 1990, the majority of researchers interested in the topic of personal finance considered themselves to be family economists, consumer economists, consumption economists, household resource management specialists, or consumer educators. Not every university had academic programs devoted solely to the study of consumer and personal finance issues. Mainstream economists and business faculty gave little attention to personal finance, focusing instead on broader issues such as the movement of money markets and the development of corporate finance principles.

Some of the early institutions that have been fully engaged in the development and offering of financial educational programs over the last three decades include Brigham Young University, College for Financial Planning, Golden Gate University, Iowa State University, Kansas State University, Ohio State University, Oklahoma State University, Purdue University, San Diego State University, San Francisco State University, Texas Tech University, The American College, University of Arizona, University of Georgia, University 
of Illinois, University of Kentucky, University of Missouri, Utah State University, and Virginia Polytechnic Institute and State University (not a complete list).

Most of these institutions offer personal finance courses, both at graduate and undergraduate levels, to prepare professionals in the field; create a body of knowledge by conducting pertinent research; and engage in outreach and professional service activities. Faculty in these programs are fully engaged with various professional societies and have built strong relationships with the financial products and services industry to prepare future graduates to meet the needs of this field. Graduates of these programs serve as educators in both formal and informal settings at various educational and governmental institutions and in private and non-private agencies. Some graduates also pursue career paths in financial planning, credit counseling, and in housing counseling areas.

Work taking place at these institutions has been broadly shared at national conferences and published in several prominent journals and conference proceedings of the national conferences of key professional societies. The Journal of Financial Counseling and Planning, the Financial Services Review, Journal of Financial Planning and the Journal of Personal Finance are solely devoted to personal finance topics. Other journals that have frequently included articles on financial issues include the Family and Consumer Sciences Research Journal, International Journal of Family and Consumer Sciences, Journal of Consumer Affairs, and Journal of Family and Economic Issues (not a complete list).

Research in the personal finance area has been based on theories from several disciplines including family studies, economics, psychology, sociology, family economics and resource management. Conceptual models that have been used by researchers take into account a broad spectrum of factors such as external and internal environments, socio- 
economic characteristics, personal characteristics (values, emotions, beliefs), and family dynamics (culture, communication). Some examples of these models are: the social exchange theory (Homans, 1958), adult learning theory (Mezirow, 1981), human ecological model (Bronfrenbrenner, 1979), family management systems (Deacon and Firebaugh,1988), lifecycle hypothesis of savings (Ando and Modigliani,1963), behavioral lifecycle hypothesis theory of reasoned action and theory of planned behavior (Thaler and Shefrin, 1981), and transtheoretical model of change (Prochaska, 1979). Nickols (2008) reported that other theories in family economics and management research include industrial engineering, organization and process, human resource theory, and ecosystems theory.

Professional societies have played a critical role in the development and strengthening of this field and the profession. Some professional societies working in this capacity for a long time include Family Economics and Home Management, a division of the American Home Economics Association (established in 1946; the new name is the American Association of Family and Consumer Sciences), American Council on Consumer Interests (ACCI, established 1953), and the Western and South Eastern Family Economics and Resource Management Associations, which were established in the late sixties and early seventies. Others, such as the Association of Financial Counseling and Planning Education (AFCPE, 1984)and the Academy of Financial Services (AFS, 1985), are relatively new and solely focused on personal financial management.

The establishment of the Association for Financial Counseling and Planning Education (AFCPE) and the Academy of Financial Services were critical events in personal finance. The seeds of these two societies were sown at Brigham Young University (BYU) 
during the informal gatherings of faculty from around the nation; both from the colleges of home economics (old name) and colleges of business, that were involved in teaching courses and conducting research in personal finance. These meetings were organized by Kay Edward, Jerry Mason, and Ginny Langrehr at BYU in 1982 and 1983. During the third meeting of this group, held in 1984 at Iowa State University and organized by the author, the group formalized itself; the Association for Financial Counseling and Planning was born. In 1985, instead of returning to the next annual meeting of AFCPE, the business faculty gathered separately; and, under the leadership of Tom Warschauer, formally organized themselves in a separate organization named Academy of Financial Services (AFS). Both the author and Warschauer were elected to be the founding presidents of their respective organizations.

Since their existence, these two organizations have focused their efforts on the development of educational programs, creation of a body of new knowledge, preparation of professionals (financial counselors and planners); and to building strong connections with practitioners in the field. Both societies hold successful annual conferences, publish prominent research journals, and continue to strengthen the field and the profession through their many efforts. Attendance at the Academy of Financial Services annual conferences in recent years are attracting faculty and graduate students from both business and traditional home economics colleges.

The Academy of Financial Services continues to strengthen its focus on research and graduate education in financial planning. It has built a strong relationship with the Financial Planning Association and the representatives of the financial products and services industry. AFCPE, on the other hand, has shown great success in building strong 
outreach and educational programs and has built strong relationships with educators in extension and the military. It currently offers several certifications for professionals, including Accredited Financial Counselor (AFC) and Certified Housing Counselors (CHC). The Academy of Financial Services works closely with the standard setting board for Certified Financial Planners (CFP Board).

\section{Financial Education in the Current Economic Environment}

Currently a great deal of attention is being drawn to this area from public, private, profit and nonprofit entities. As concerns about consumers' financial capability have increased, so too have the number and variety of financial education programs and program providers. However, some programs offer comprehensive information on a variety of topics for a broad audience, including savings, credit, risk management, investments, retirement planning and similar topics. Others are focused on a single topic such as credit management, retirement planning, and investing; and they are tailored to a specific group, such as youth, women, or minorities (Braunstein and Welch, 2002). Many are providing financial education to students, employees, customers, the general public and more; and most of these educational efforts are being presented under the name of "financial literacy."

However, multiple names are being used to identify teaching and research work that is being done in personal finance. Some of the names that have been used for a long time include Consumer Economics, Consumer Affairs, Family and Consumer Sciences, Family Economics, Family Economics and Resource Management, Family Finance, Family Financial Management, Household Economics, and Personal Finance. More recent names include Household Finance, Household Behavioral Finance and Financial Literacy. 
Since the 1990s, the use of the term financial literacy has gained momentum; however, popularization of the term has created confusion. A web search on financial literacy returns nearly two million results. There are financial literacy programs, tests, statistics, and training. Most are general, but some target audiences such as teens or preretirees. Most of these programs have different goals and different outcome expectations. There is no common agreement on the core content, overall and specific objectives, the qualifications of the deliverers of these courses, and for the assessment of the outcomes (Hira and Schuchardt, 2008).

Most disciplines such as math, economics, history, sociology, and psychology are usually identified by one name only. There are specialties or concentrations for each of these disciplines, but only one name. To reduce the confusion, there must be one name for financial education; and more importantly, there must be a common understanding of what can be expected from such courses. Before this can be accomplished, some basic questions must be answered: what is the overall objective, what is the core content, what competencies and skills must the learner gain, what preparation or qualifications must the teachers of financial education have, and what standards must be used to assess the outcomes of such programs?

\section{Overall Goal for Financial Education}

The overall goal for financial education is to ensure that everyone is equipped with appropriate information, knowledge, and skills to make good financial decisions. The challenge to educators is to determine what specific skills people need in order to understand the long-term costs and benefits of their financial decisions (Hira, 1995). Financially educated consumers are an important first line of defense in well-functioning 
markets. At the same time, it is important to recognize that financial education is not a panacea and that there remains a need for effective regulation that is responsive to market evolutions to ensure that consumers are protected against abusive and fraudulent practices by unscrupulous players.

\section{Financial Education: Definition and Core Content}

The U.S. President's Advisory Council on Financial Literacy was established in 2008. The Executive Order creating the Council established, for the first time, that it is "the policy of the Federal government to encourage financial literacy among the American people." Then-President Bush and Secretary of the Treasury Henry Paulson tasked the Council to work with the public and private sector to help increase financial education efforts for youth in school and for adults in the workplace, increase access to financial services, establish measures of national financial literacy, conduct research on financial knowledge and to help strengthen public and private sector financial education programs. The market turmoil and credit crisis of 2008 underscore the critical need for improved financial education (U.S. Department of the Treasury, Office of Financial Education, 2008). The Council's report describes "financial education" as:

The process by which people improve their understanding of financial products, services and concepts, so they are empowered to make informed choices, avoid pitfalls, know where to go for help and take other actions to improve their present and long-term financial wellbeing." (Recommendation 11, p. 35)

Additionally, financial education must also help learners clarify their values and goals, distinguish between needs and wants, and recognize limits of their financial resources; 
these programs must be tailored to their target audiences, taking into account language, literacy level, culture, age and experiences.

Recommendation \#12 of the Council's report emphasizes the importance of developing standards by recommending that:

The United States Department of the Treasury should identify and standardize the specific skills that a person should have upon completion of a comprehensive financial literacy program and explore the creation of a certification program for such programs and for the instructors of the programs that meet the criteria (p. 4). The Council asserts that any individual completing a "comprehensive financial literacy program" should have an understanding of the following skills and concepts:

o the capital market system and financial institutions;

o how to develop and maintain positive cash flow;

o how to develop a spending plan that is consistent with their resources and priorities;

o the reasons for having an emergency fund and how to establish an emergency fund;

o the fundamentals of credit granting, including how to evaluate, select, and manage credit, and how to maintain a good credit rating;

o the process of deciding when to rent and when to buy a home, and the process of home ownership;

o the process of identifying various financial risks, including development of a risk management strategy to decide which risks they should take on and which should be transferred to an insurance provider; 
0 how to identify and protect themselves from identity theft and various financial frauds, and what to know and do if they think they have been victimized;

o basic investment products, the relationship between risk and return, and the what, when and why of choosing the best investments at the right time in their life;

o how to evaluate and take advantage of employee benefits and taxadvantaged savings accounts; and

o the various components of retirement planning, and how to develop an appropriate plan for a secure retirement, how to develop a plan to assure financial security in the case of unexpected loss of income (disability or death) for those who depend on their earning power, and to assure the smooth transfer of assets to appropriate heirs. (pp. 36-37)

\section{Does Financial Education Work?}

Bell, Gorin and Hogarth, in a recent study (2009), report that financial education does seem to have an effect on specific financial management behaviors. Those taking a financial education program are more likely than the comparison group to report using formal spending plans and less likely to report using informal spending plans] This study also finds that high school financial education programs make a difference in selected behaviors: those who have a high school financial education course are more likely to have a savings account for short-term savings goals and to save regularly. Having taken a high school course is also associated with having fewer overdraft fees in the past six months. Early financial management experience also seems to matter: those who have a high school 
savings account are more likely to have an emergency fund, more likely to read money management articles, and less likely to "never" pay off their credit card balances.

However, Cole and Shastry (Harvard Business School, 2009), using the U.S. Census long form, examined the saving behavior of people in states with a literacy mandate, comparing those who graduated before and after the enactment of the mandate, and find that the introduction of the mandate has no effect. Similarly, Mandell and Klein (2009) find that high school courses in personal finance or money management have done little to raise the level of financial literacy among young adults. In an earlier study, Mandell (2006) reported similar findings. Students who take a course in personal finance end up no more financially literate than those who do not. Tracking students who took such a course over a five year period shows no positive impact on financial literacy, attitudes toward thrift, or behavior. However, Bernheim, Garrett, and Maki in their 2001 study find that people who live in states that mandated financial education in high schools are more likely to report having taken a financial literacy course and also save at higher rates.

Danes, Huddleston-Casas, and Boyce (1999) conducted a study to assess the impact of a high school financial planning curriculum on the financial knowledge, behavior, and self-efficacy of a national sample of teens using the curriculum. They report that statistically significant changes are found in financial knowledge, behavior, and self-efficacy both immediately after studying the curriculum and three months after completing the curriculum. About half the teens show gains in knowledge, a third demonstrate gains in behavior, and $40 \%$ increase their confidence in managing their money.

Xiao, Newman, Prochaska, Leon, Bassett, and Johnson (2004) argue that although financial education can be beneficial and can have a positive impact on the lives of 
consumers, the nature of the impact and its level of effectiveness are often difficult to measure. Furthermore, impacts may not be immediate, but education may be instrumental in starting the process of behavior change or moving people from one stage of behavior to another.

Willis (2008), on the other hand, argues that the financial literacy education model is premised on the promise of consumer sovereignty-that consumers can be taught to make welfare-enhancing choices in the insurance, credit, and investment marketplace, trained to read and travel the road map to the American dream. The model dupes consumers into thinking they can master the financial services market, while placing blame upon them for their failure to do so, deflecting political pressure for change. Researchers and practitioners continue to debate the rigor of various evaluation techniques and the appropriate measures to use (Lyons, 2005).

Braunstein and Welch (2002) suggest that some programs, particularly those having discrete objectives, have succeeded in improving certain aspects of consumers' personal financial management, such as maintaining a mortgage, increasing savings, or participating in employer sponsored benefit plans. Improved financial behavior does not necessarily follow from increased financial information. The timing and format of training, as well as human traits such as aversion to change, play a role in whether programs will effect positive change that contributes to households' long-term financial wellbeing. Accounting for all the variables associated with financial literacy training-when, how, and where it is delivered, who is trained, and what information is presented-poses a great challenge for program developers. Given the resources now devoted to financial literacy training, this is an opportune time to evaluate the research, identify best practices, and 
consider public policy options that would further the goal of creating more financially savvy consumers.

\section{Future Opportunities and Challenges}

In the past, professionals in the family economics and management field of personal finance made use of the interdisciplinary approach to study financial behavior. Today, professionals from those disciplines (economics, sociology, psychology, and many others) are studying financial behavior, expanding opportunities and potential for a stronger and richer discipline. Opportunities for transdisciplinary work offer a great promise for the future. The discipline must meet the challenges of creating an environment where professionals from various disciplines create strong connections, collaborate, and generate truly interdisciplinary studies.

A report prepared by the U.S. Government Accountability Office in 2004 clearly identifies the challenges and opportunities that lie ahead. It suggests that establishing standards for core content and outcome objectives is critical for the development of evaluation and assessment instruments so that there can be matched areas consistent with the goals and appropriate for the target audience. Furthermore, it is important to differentiate between measuring outcomes of a course and the outcome of an intervention such as advising and counseling, designed to bring about a predetermined behavior change. Asking different questions, using different measures, and comparing courses with different objectives and taught by instructors of various professional qualifications is likely to yield different results. This report also identified the need for setting standardized benchmarks 
and developing a federal evaluation infrastructure to help nonprofits and other organizations build evaluation capacity.

Braunstein and Welch (2002) have a few unique ideas for delivering financial education. They suggest something similar to the use of a credit-scoring model in loan underwriting, which has enabled lenders to quickly and effectively construct an individual risk profile. A similar approach might be taken in determining a consumer's financial literacy profile, with a database on an individual's or group's financial status, behavior, and learning preferences used to identify an individual's information and educational needs. Knowledge of those needs, coupled with an assessment of the individual's motivation and confidence, could assist in providing relevant financial information at the appropriate time.

They also argue that development of consistent standards for measuring results could increase the success of financial literacy programs. Practitioners who can demonstrate the effectiveness of their programs can contribute significantly to the identification of "best practices" and the setting of policies that may lead to consumers who are better equipped to survive and, more important, thrive in our vibrant, diverse, complex financial marketplace.

The most important challenge facing the profession today is the use of multiple names and confusion about what could be expected from programs that are labeled as financial literacy. Clarifying the vision and mission, identifying the outcome goals to determine the core content of a financial education program and expectations from the educators-outcome goals, setting standards for qualification of the educator/advisor to prepare financial educators with knowledge and skills, and measuring effectiveness of educational efforts-are steps which will undoubtedly result in improved outcomes. 
In conclusion, strengthening the profession requires defining or redefining the mission; agreeing upon one name for the field; determining the content of a basic personal finance curriculum that stretches from K-12 to college; identifying core competencies; determining qualifications of those who teach or advise individuals of all ages; setting standards to evaluate quality of programs; setting standards to measure the effectiveness of financial education; conducting much-needed research; and developing practical implications of research for the benefit of individuals, educators, and policy makers.

There is a critical need for a national forum to bring about an agreement on the one name, core content and competencies, and professional qualifications for the personal financial field. This is necessary for future growth and development of the profession. 


\section{References}

Ariely, D. (2009). "The End of Rational Economics." Harvard Business Review 87 (7/8), 7884. Retrieved October 4, 2009, from http://web.ebscohost.com.proxy.lib.iastate.edu:2048/ehost/pdf?vid=5\&hid=3\&sid= 57f70c81-f816-40c0-8ee3-2ebf691e2032\%40sessionmgr11

Ando, A., and Modigliani, F. (1963). "The Life Cycle Hypothesis of Saving: Aggregate Implications and Tests." American Economic Review 53, 55-84.

Bernheim, B. D., Garrett, D. M. and Maki, D. M. 2001. "Education and Saving: The Long-Term Effects of High School Financial Curriculum Mandates." Journal of Public Economics

80

(3), 435-465.

Bell, C., Gorin, D. and Hogarth, J. M. (2009). “Does Financial Education Affect Soldiers' Financial Behavior?" Networks Financial Institute at Indiana State University, Working Paper 2009-WP-08. August. Retrieved October 3, 2009 from http://www.networksfinancialinstitute.org/Lists/Publication\%20Library/Attachm ents/140/2009-WP-08 Bell Gorin Hogarth.pdf.

Beller, A. H. and Kiss, D.E. (1999). “On the Contribution of Hazel Kyrk to Family Economics.” Paper prepared for presentation at the Society for the Advancement of Behavioral Economics meeting, Exploring the Reorientation of Economics, San Diego, California, June 12-14.

Braunstein S., and Welch, C. (2002). "Financial Literacy: An Overview of Practice, Research, and Policy." Federal Reserve Board, Division of Consumer and Community Affairs. Retrieved October 3, 2009 from http://www.federalreserve.gov/pubs/bulletin/2002/1102lead.pdf

Bronfrenbrenner, U. (1979). The Ecology of Human Development. Cambridge: Harvard University Press.

Campbell, J. Y. (2006). “Household Finance.” Journal of Finance 61 (4), 1553-1604.

Coben, D. (Ed.) (2003). "Adult Numeracy: Review of Research and Related Literature." London: National Research and Development Centre for Adult Literacy and Numeracy.

Cole, S. and Shastry, G. K. (2009). "Smart Money: The Effect of Education, Cognitive Ability, and Financial Literacy on Financial Market Participation." Harvard Business School (Working Paper No. 09-071). January.

Danes, S. M., Huddleston-Casas, C., and Boyce, L. (1999). “Financial Planning Curriculum For 
Teens: Impact Evaluation." Financial Counseling and Planning 10 (1), 26-39.

Deacon, R. E., and Firebaugh, F. M. (1988). Family Resource Management: Principles and Applications ( $2^{\text {nd }}$ ed.). Boston: Allyn \& Bacon.

Ginsburg, L., Manly, M., and Schmitt, M. J. (2006). "The Components of Numeracy." National Center for the Study of Adult Learning and Literacy, Harvard Graduate School of Education. Retrieved October, 4, 2009, from http://www.ncsall.net/fileadmin/resources/research/op_numeracy.pdf

Hogarth, J. M. (2002). "Financial Literacy and Family and Consumer Sciences." Journal of Family and Consumer Sciences 94 (1), 15-28.

Homans, G. C. (1958). “Social Behavior as Exchange.” American Journal of Sociology 63 (6), 597-606.

Hira, T. K. (1995). "Family Resource Management Approach to Moderating the Effect of Toxic Environment on Children." Invited response to James Garbarino's keynote address at the 2nd General Session of American Association of Family and Consumer Sciences, New Orleans, Louisiana.

Hira T. K., and Schuchardt, J. (2008). "Setting the Standard for Financial Literacy." AFCPE Forum. The Standard, 4th Quarter, 26 (4), 1, 11.

Lyons, A. C. (2005). "Financial Education and Program Evaluation: Challenges and Potentials for Financial Professionals." Journal of Personal Finance 4 (4), 56-68.

Mason, C. L. J. and Wilson, R. M. S. (2000). “Conceptualizing Financial Literacy.” Occasional Paper, 2000:7. Business School, Loughborough University.

Mandell, L. (2006). “Financial Literacy: If it’s so Important, Why Isn't it Improving?" Networks Financial Institute at Indiana State University. April. Policy Brief 2006-PB08. Retrieved October, 3, 2009 from http://www.networksfinancialinstitute.org/Lists/Publication\%20Library/Attachm ents/30/2006-PB-08 Mandell.pdf

Mandell, L. and Klein, L. S. (2009). "The Impact of Financial Literacy Education on Subsequent Financial Behavior." Journal of Financial Counseling and Planning 20 (1), 15-24.

Mezirow, J. (1981). "A Critical Theory of Adult Learning and Education." Adult Education Quarterly 32 (3), 24.

Nickols, S. Y. (2008). "From Treatise to Textbooks: History of Writing About Household Management." Family and Consumer Sciences Research Journal 37,111-139. 
Prochaska, J. O. (1979). Systems of Psychotherapy: A Transtheoretical Analysis. Homewood, IL. Dorsey.

Schuchardt, J., Bagwell, D. C., Bailey, W. C., DeVaney, S. A., Grable, J. E., Leech, R. E., Lown, J. M., and Xiao J. J. (2007). "Personal Finance: An Interdisciplinary Profession." Journal of Financial Counseling and Planning 18 (1), 61-69.

Simon, H. A. (1947). Administrative Behavior. NY: The Free Press.

Thaler, R. H. and Shefrin, H. M. (1981). "An Economic Theory of Self-Control." The Journal of Political Economy 89 (2), 392-406.

United States Department of the Treasury, Office of Financial Education. (2008). “2008 Annual Report to the President of the President's Advisory Council on Financial Literacy." Washington, DC. Retrieved October, 3, 2009 from http://www.jumpstartcoalition.org/PACFL_ANNUAL_REPORT_1_16_09.pdf

United States Government Accountability Office. (2004). "Highlights of a GAO Forum: The Federal Government's Role in Improving Financial Literacy." GAO Publication No. GAO-05-93SP. Washington, DC. November. Retrieved October, 3, 2009 from http://www.gao.gov/new.items/d0593sp.pdf

Willis, L.E. (2008). "Against Financial-Literacy Education." Iowa Law Review 94 (1), 197285.

Xiao, J. J., Newman, B. M., Prochaska, J. Leon, B.; Bassett, R. L.; \& Johnson, J. L. (2004). "Applying the Transtheoretical Model of Change to Consumer Debt Behavior." Financial Counseling and Planning 15 (2), 89-100. 